\title{
Kazuistika I Case report \\ Cardioembolic stroke as consequence of myocardial infarction: case report and concise review
}

\author{
Ondřej Černý, Tomáš Roubíček, Jindřich Kupec, Rostislav Polášek
}

Department of Cardiology, Regional Hospital Liberec, Liberec

\section{ARTICLE INFO}

Article history:

Submitted: 7. 112017

Accepted: 10. 7. 2018

Available online: 31. 5. 2019

\section{Klíčová slova:}

Infarkt myokardu

Kardioembolizační iktus

Mozková ischemie

Poinfarktové komplikace

\section{Keywords:}

Cardioembolic stroke

Cerebral ischemia

Myocardial infarction

Postinfarction complications

\section{SOUHRN}

Přes značný pokrok v léčbě infarktu myokardu jsou jeho tromboembolické komplikace nadále velmi závažné a jejich prognóza nezřídka fatální. Poinfarktový kardioembolizační iktus je nejčastější z podtypů ischemické cévní mozkové př́hody a má z nich také nejhorší prognózu. $V$ předložené kazuistice popisujeme kardioembolizační cévní mozkovou príhodu z apikálního aneurysmatu levé srdeční komory coby první symptom proběhlého infarktu myokardu vedoucí k vyhledání lékařské pomoci. V navazujícím stručném přehledu literatury dále diskutujeme hlavní rizikové faktory, diagnostický algoritmus, antikoagulační strategii a prognózu poinfarktového kardioembolizačního iktu.

(c) 2019, ČKS.

\section{ABSTRACT}

Despite tremendous achievements in myocardial infarction therapy, thromboembolic complications remain very serious and its prognosis often fatal. Postinfarction cardioembolic stroke is the most frequent and has the highest mortality of all ischemic stroke subtypes. In this case report we describe cardioembolic stroke from postinfarction apical left ventricular aneurysm as a first symptom of myocardial infarction. In brief literature overview we discuss main risk factors and prognosis, diagnostic algorithm and anticoagulation strategy.

\section{Introduction}

Heart diseases in general are major risk factors for stroke following age and hypertension. ${ }^{1}$ Despite the fact that mortality caused by acute myocardial infarction (MI) has decreased since percutaneous coronary intervention (PCl) has become standard of care, postinfarction complications still lead to morbidity and mortality in large number of patients. One of the most feared MI complications is the occurrence of thromboembolic event (mostly cerebrovascular accidents) due to left ventricular (LV) thrombus formation in aneurysmatic cavity. ${ }^{2}$ We present a case report of ischemic stroke as the first symptom of MI.

\section{Case report}

Fifty-three-year-old man with a medical history of arterial hypertension and type II diabetes mellitus was transferred to emergency department with rapid onset of aphasia.
Three weeks ago the patient had history of respiratory infect empirically treated with antibiotics. Standardized admission examination (including ECG) was performed. The patient was seen by neurologist with finding of acute ischemic stroke. Native brain CT verifying the clinical suspicion was directly performed and atypical multiple hypodensities in all cerebral lobi found. Brain magnetic resonance (MRI) demonstrated sequential ischemic strokes in different cerebral artery territories (Fig. 1). Embolization was suspected as the most probable mechanism.

Based on recent respiratory infect medical history and elevated acute inflammatory reactants, infection was thought to be the most probable emboligenic condition. To exclude infective endocarditis as a source of embolisation, cardiologist was contacted and transesophageal echocardiography required. Shortly after, upon patient's medical history and mainly 12-lead ECG depicting anteroextensive LV aneurysm (Fig. 2), cardioembolic stroke as a late complication of ambulatory anterior transmural MI was started to be considered as the most probable mechanism. This suspi- 


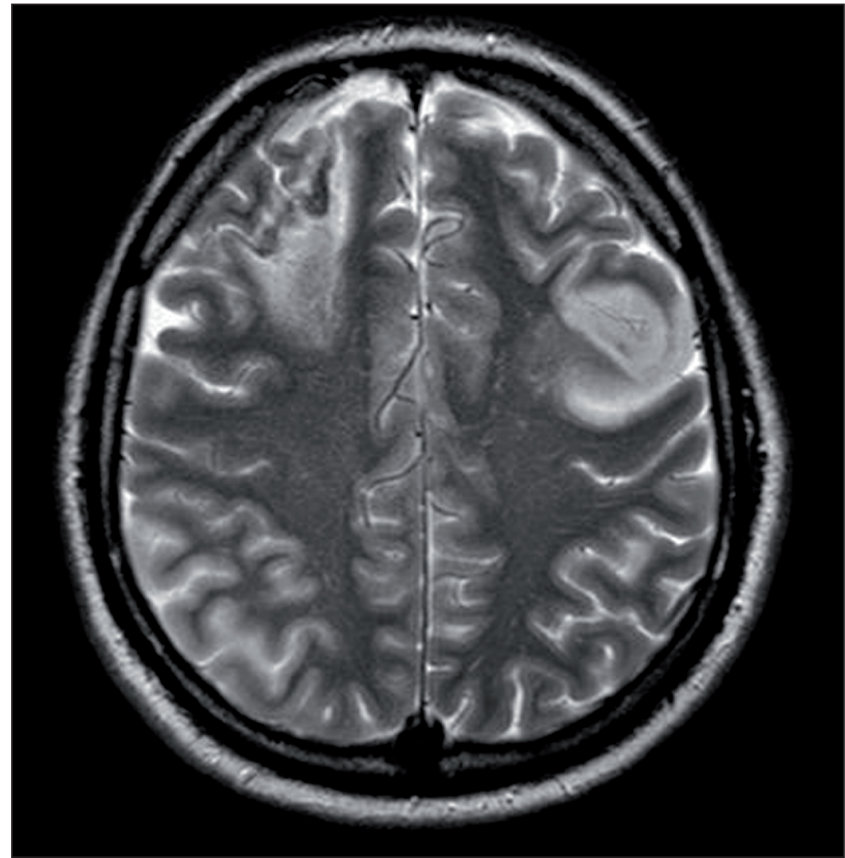

Fig. 1 - Magnetic resonance image with hypodensities of various age in different cerebral artery territories. cion was consequently strengthened by transesophageal echocardiography (TEE, Fig. 3) finding of apical LV aneurysm with mobile thrombi. Left ventricle ejection fraction was severely reduced (LV EF 35\%). Postinfarction cardioembolic stroke origin was further worked out by detailed medical history gained from patient's family: three weeks before the stroke the patient complained for 48 hours lasting chest pain with vomiting.

Acetylsalicylic acid and therapeutic dose of enoxaparine was initiated immediately. Follow-up native brain $\mathrm{CT}$ performed during the hospitalization showed diminishing ischemic brain lesions. Two of these lesions subsequently underwent hemorrhagic conversion. The dose of anticoagulation by subcutaneous enoxaparin was lowered after the hemorrhagic conversion and was continued three months after the stroke. Control TEE showed full resolution of intraventricular thrombi. Selective coronarography was not performed because of organic brain syndrome. Standard pharmacotherapy including ramipril, bisoprolol, and rosuvastatin was titrated according to ESC guidelines. Although transient hemiparesis markedly slowed patien$t$ 's recovery, he was after twenty-one days of ICU care and subsequent fifteen days in psychiatric ward dismissed home. However, he remained moderately disabled in usual daily

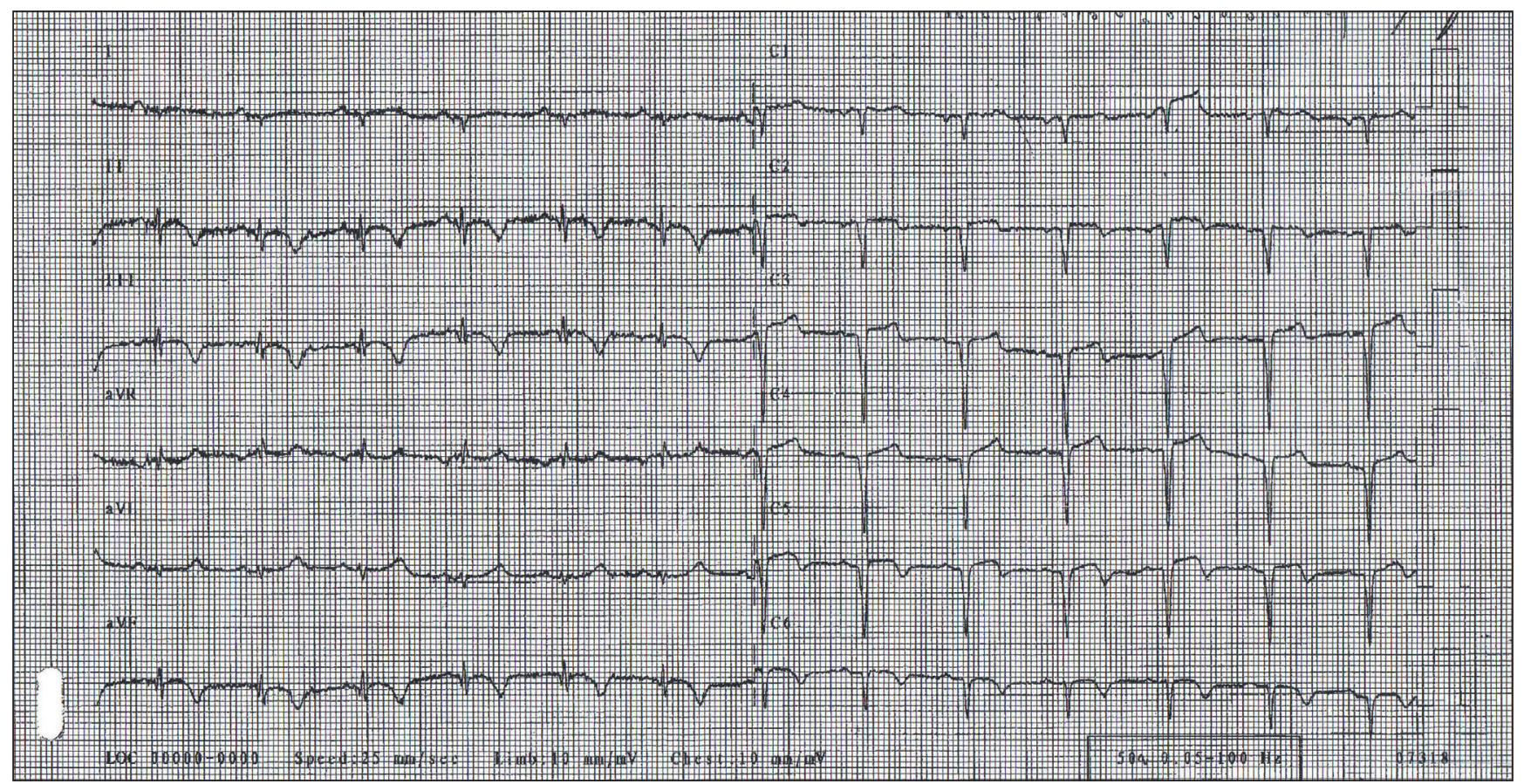

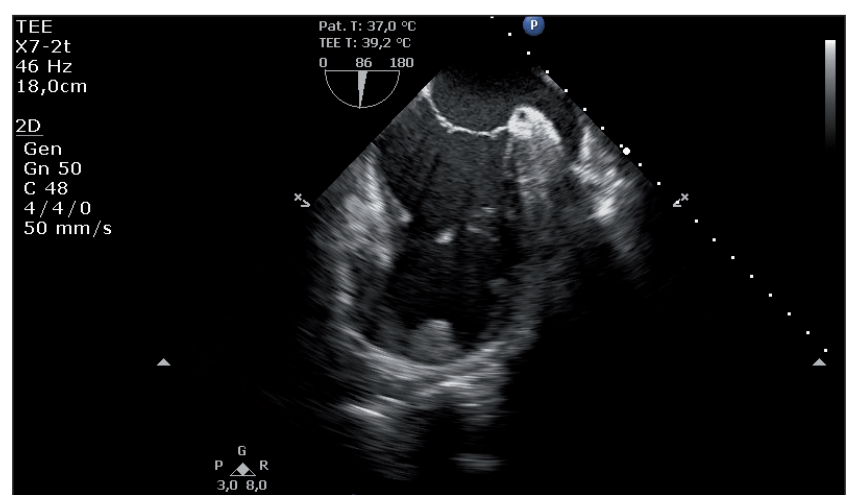

Fig. 3 - Transoesophageal echocardiography depicting left ventricular thrombus in apical aneurysm.
Fig. 2 - 12-lead ECG with anteroextensive left ventricular aneurysm pattern.

activities by moderate dementia impairment (mRS - Modified Rankin Scale for Neurological Disabilities = 3, MMSE Mini-Mental State Examination $=12$ points out of 30 ).

\section{Discussion}

Generally, cardioembolic ischemic strokes are frequent and their prognosis is often fatal. In total, as reviewed by Arboix et Alio, ${ }^{3}$ cardioembolic ischemic strokes cause 
$14-30 \%$ of all ischemic strokes and have the highest in-hospital mortality up to $26 \%$. Their clinical presentation is characterized by sudden neurological deficits maximal at onset due to abrupt blood flow interruption. ${ }^{4}$ Non-cardioembolic strokes can appear with sudden deficits in two-fifths of cases. ${ }^{5}$ Rapid regression of symptoms reflecting early recanalization has also been related to cardioembolic stroke. ${ }^{6}$ Some neurological syndromes such as receptive aphasia, global aphasia without hemiparesis, Wallenberg's syndrome, and cerebellar infarcts have been commonly associated with cardiac embolism. Visual field abnormalities, neglect syndrome and aphasia are clinical deficits more frequent in cardioembolic stroke. Neuroimaging findings that support cardioembolic stroke include simultaneous or sequential strokes in different arterial territories. ${ }^{7}$ The presence of a potential major cardiac source of embolism in the absence of significant arterial disease remains the mainstay of clinical diagnosis of cardioembolic cerebral infarction. In many patients their history, physical examination, and routine diagnostic tests (electrocardiogram and findings on neuroimaging studies) are sufficient to make the diagnosis of most presumed cardiac emboligenic condition (atrial fibrillation, recent $\mathrm{MI}$, heart failure). ${ }^{8}$

Postinfarction cardioembolic stroke represents a pathogenic mechanism which joins together two of the most frequent and most feared cardiovascular diseases, MI and stroke. Since there are various potential mechanisms of cardioembolic stroke including atrial fibrillation, infective endocarditis or paradoxical embolism, no simple test to detect postinfarction cardioembolic stroke exists.

Correct diagnosis is based on stroke clinical characteristics (sudden onset, type of neurological deficits, potential rapid regression) and neuroimaging results. For cardiologist are most important patient's medical history, 12-lead ECG and transthoracic echocardiography (TTE) or TEE results.

In FRAMI study, postinfarction cardioembolic stroke with CT-verified cerebral ischemia was found in $1 \%$ of patients after anterior $\mathrm{MI}$ treated with system fibrinolysis. ${ }^{9}$ As in our times primary $\mathrm{PCl}$ is the preferred reperfusion strategy and most papers about this topic have been published in fibrinolytic era, only little is known about contemporary postinfarction cardioembolic stroke prevalence. PCl-related cardioembolic stroke is infrequent, but serious post- $\mathrm{PCl}$ complication with significantly more complications than control group. ${ }^{10}$ Post-procedure cardioembolic stroke is the most frequent stroke type shortly after $C A B G$, where overall postprocedure stroke incidence is about $4 \% .{ }^{11}$ Late ischemic stroke after MI may be often a direct consequence of the sequelae of MI due to LV thrombus formation in aneurysmatic cavity. ${ }^{2}$ Higher Killip class and significantly higher cardiospecific enzymes are related to LV thrombus formation. ${ }^{12}$ More than one half of cardioembolic MI occurs before the fifth day after MI. ${ }^{13}$ Age, male gender, hypercholesterolemia and claudication were identified as independent risk factors for cardioembolic stroke after MI. ${ }^{14}$ Mobile thrombi demonstrate significantly higher embolization potential than sedentary ones. ${ }^{15}$ LV aneurysm or dyskinesia was proven to increase the risk of ischemic stroke. ${ }^{16,17}$ Early LV throm- bus development has been identified as an independent mortality predictor for patients with acute anterior $\mathrm{MI}$ treated with systemic thrombolytic therapy. ${ }^{18}$

TEE provides a valuable tool for diagnosis of cardioembolic stroke increasing the likelihood of identifying a source of stroke by two- to fourfold probability compared with transthoracic echocardiography (TTE). ${ }^{19}$ TEE also appears to be superior upon cardiac magnetic resonance (CMR) in finding potential sources of cardioembolism..$^{20}$ According to recent studies, reduced LV EF has been identified as a predictor of mortality in ischemic stroke patients. ${ }^{21-23}$

Our case report illustrates typical features of postinfarction cardioembolic stroke mechanisms in cardiovascular as good as neurological aspects. When described and discussed as a case report, all diagnostic steps mentioned above might seem to be easy and logical. Nevertheless, correct diagnosis in our patient was found 48 hours after the first medical contact. Apparently, such a long time could and probably should be reduced. Cardioembolic etiology of ischemic cerebral stroke has been identified as the most frequent one by Kolomincky-Rabas et al. ${ }^{24}$ and Král et al. ${ }^{25}$ It is most often a neurologist, who is in our hospital emergency system called to the stroke patient first. As favors in present paper, ${ }^{26}$ patients with current clinical diagnosis of stroke/TIA could be divided with significant level of accuracy into presumed cardioembolic or non-cardioembolic group just by clinical judgement of neurologist without further cardiological assessment. Cardiologist should be contacted immediately after such empiric division. This proactive attitude of neurologists could fasten diagnostic process and direct to appropriate diagnosis earlier.

Anticoagulation with warfarin for three months after ischemic stroke/TIA in the settings of acute MI with detectable LV mural thrombus is recommended according to AHA/ASA guidelines (recommendation class I, level of evidence C). Anticoagulation should be considered also for patients with ischemic stroke/TIA in the settings of acute anterior $\mathrm{MI}$ without mural thrombus but with detected anterior apical akinesis or dyskinesis (recommendation class IIb, level of evidence C). ${ }^{27}$ There is ongoing discussion over optimal anticoagulation treatment of patients with postinfarction intraventricular thrombi. Whereas prophylactic anticoagulation failed to reduce left ventricular thrombus formation during subacute phase of $\mathrm{Ml}^{28}$ and according some data chronic anticoagulation failed to reduce long-term LV thrombi formation rate, ${ }^{18}$ long-term anticoagulation therapy still remains the cornerstone in therapy and cardioembolic stroke prevention when thrombus in postinfarction LV aneurysm appears. ${ }^{29}$ When acute $\mathrm{MI}$ was treated just with acetylsalicylic acid (ASA) plus fibrinolysis with streptokinase (without anticoagulation), no significant difference in LV thrombus formation rate between fibrinolysis and non-fibrinolysis group was found. ${ }^{30}$ In FRAMI study, ${ }^{9}$ subcutaneous dalteparin + ASA significantly reduced LV thrombus formation rate. As stated in ${ }^{16}$, statistically significant difference in embolic event rate between long-term anticoagulated and non-anticoagulated group of patients with LV thrombus after MI treated with fibrinolysis was found. Low molecular heparins (LMWH) were recommended for long-term anticoagulation in patients with postinfarction LV throm- 
bus despite their usage was connected with hemorrhagic complications. ${ }^{9}$ In a randomized open multicenter study WARIS II comparing three tactics in secondary prevention after $\mathrm{MI}^{31}$ - single warfarin anticoagulation (with INR 2.8 to 4.2), antiagregation with ASA (160 mg daily) and combination therapy (ASA $75 \mathrm{mg}$ daily + warfarin to INR 2.0-2.5), significantly lower primary endpoint rate (death, non-fatal reinfarction, thromboembolic cerebral stroke) between both groups using warfarin in comparison with ASA-only group was found. In the same study, major nonfatal bleeding rate was significantly higher in both groups using warfarin. Non-vitamin K antagonist oral anticoagulants (NOACs - dabigatran, rivaroxaban and apixaban) or LMWH anticoagulation for 3 months may be considered in patients with ischemic stroke in the settings of acute MI complicated with LV mural thrombus formation or anterior or apical wall motion abnormalities in case of warfarin intolerance or non-hemorrhagic adverse events according to AHA/ASA guidelines ${ }^{27}$ (recommendation class IIb, level of evidence C). NOACs significantly decreased the severity of cardioembolic stroke on admission and patient group treated with them showed better functional outcome in a single-center observational study focused on non-valvular atrial fibrillation (NVAF) cardioembolic ischemic stroke. ${ }^{32}$ In observational study, ${ }^{33}$ NOACs were identified to reduce the severity of NVAF cardioembolic stroke and patient group treated with NOACs demonstrated better functional outcome than not-anticoagulated and warfarin low-anticoagulated group. According to contemporary AHA/ASA stroke prevention guidelines, ${ }^{27}$ NOAC therapy may be considered for patient described in this case report above just in case of warfarin intolerance because of non-hemorrhagic adverse events. Level of evidence for this recommendation is low (C-consensus of experts).

From two alternatives of anticoagulation described above (warfarin taken orally versus LMWH taken subcutaneously) we have chosen the subcutaneous one. This was done upon clinical decision because of patient's moderate dementia impairment and better control of subcutaneous treatment. In case report described, intraventricular thrombi disappeared when subcutaneous enoxaparin treatment was initiated. Nevertheless, as mentioned above, two of ischemic brain lesions subsequently underwent hemorrhagic transformation.

Third anticoagulation possibility - peroral therapy with NOACs was not used primarily because of way of administration (inability to swallow) and secondary because only little is contemporarily known about the role of NOACs in secondary postinfarction cardioembolic stroke prevention.

As depicted in case reports described in ${ }^{16}$, prophylactic systemic fibrinolysis of postinfarction LV mobile thrombi, although effective, led to serious secondary cardioembolic complications and is connected with at least one fatal cardioembolic stroke.

\section{Conclusion}

Postinfarction cardioembolic stroke remains one of the most dangerous postinfarction complication with high mortality and serious morbidity. Its contemporary prevalence is presumably underestimated. Correct diagnosis is based on detailed medical history, ECG, TTE/TEE and neuroimaging results. Diagnostic process is often complicated and slower than optimal. Long-term anticoagulation should be used in stroke secondary prevention in patients with LV intraventricular thrombus or LV motion abnormalities.

\section{Conflict of interest}

None declared.

\section{Funding body}

None.

\section{Ethical statement}

Authors state that the research was conducted according to ethical standards.

\section{Informed consent}

Informed consent was obtained from the patient participating in this study.

\section{References}

1. Appelros P, Nydevik I, Seiger A, Terént A. Predictors of severe stroke: influence of preexisting dementia and cardiac disorders. Stroke 2002;33:2357-2362.

2. Delewi R, Zijlstra F, Piek JJ. Left ventricular thrombus formation after acute myocardial infarction. Heart 2012;98:1743-1749.

3. Arboix A, Alio J. Acute cardioembolic cerebral infarction: answers to clinical questions. Curr Cardiol Rev 2012;8:54-67.

4. Kittner SJ, Sharkness CM, Price TR, et al. Infarcts with a cardiac source of embolism in the NINCDS Stroke Data Bank Historical features. Neurology 1990;40:281.

5. Arboix A, Oliveres M, Massons J, et al. Early differentiation of cardioembolic from atherothrombotic cerebral infarction: a multivariate analysis. Eur J Neurol 1999;6:677-683.

6. Minematsu K, Yamaguchi T, Omae T. "Spectacular shrinking deficit": rapid recovery from a major hemispheric syndrome by migration of an embolus. Neurology 1992;42:157-162.

7. Bogousslavsky J, Cachin C, Regli F, et al. Cardiac sources of embolism and cerebral infarction - clinical consequences and vascular concomitants: the Lausanne Stroke Registry. Neurology 1991;41:855-859.

8. Ustrell X, Pellisé A. Cardiac Workup of Ischemic Stroke. Curr Cardiol Rev 2010;6:175-183.

9. Kontny F, Dale J, Abildgaard U, Pedersen TR. Randomized trial of low molecular weight heparin (dalteparin) in prevention of left ventricular thrombus formation and arterial embolism after acute anterior myocardial infarction: the Fragmin in Acute Myocardial Infarction (FRAMI) Study. J Am Coll Cardiol 1997;30:962-969.

10. Hoffman SJ, Holmes DR, Rabinstein AA, et al. Trends, predictors, and outcomes of cerebrovascular events related to percutaneous coronary intervention: a 16-year single-center experience. JACC Cardiovasc Interv 2011;4:415-422.

11. Likosky DS, Marrin CAS, Caplan LR, et al., Northern New England Cardiovascular Disease Study Group, Determination of etiologic mechanisms of strokes secondary to coronary artery bypass graft surgery. Stroke 2003;34:2830-2834.

12. Visser CA, Kan G, Meltzer RS, et al. Long-term follow-up of left ventricular thrombus after acute myocardial infarction. A two-dimensional echocardiographic study in 96 patients. Chest 1984;86:532-536.

13. Mooe T, Eriksson P, Stegmayr B. Ischemic stroke after acute myocardial infarction. A population-based study. Stroke 1997;28:762-767. 
14. Martín R, Bogousslavsky J. Mechanism of late stroke after myocardial infarct: the Lausanne Stroke Registry. J Neurol Neurosurg Psychiatry 1993;56:760-764.

15. Visser CA, Kan G, Meltzer RS, et al. Embolic potential of left ventricular thrombus after myocardial infarction: a two-dimensional echocardiographic study of 119 patients. J Am Coll Cardiol 1985;5:1276-1280.

16. Keren A, Goldberg S, Gottlieb S, et al. Natural history of left ventricular thrombi: their appearance and resolution in the posthospitalization period of acute myocardial infarction. J Am Coll Cardiol 1990;15:790-800.

17. MacDougall NJ, Amarasinghe S, Muir KW. Secondary prevention of stroke. Expert Rev Cardiovasc Ther 2009;7:11031115.

18. Mooe T, Teien D, Karp K, Eriksson P. Long term follow up of patients with anterior myocardial infarction complicated by left ventricular thrombus in the thrombolytic era. Heart 1996;75:252-256.

19. Rodriguez C, Homma S, Di Tullio M. Transesophageal Echocardiography in Stroke. Cardiol Rev 2000;8:140.

20. Zahuranec DB, Mueller GC, Bach DS, et al. Pilot study of cardiac magnetic resonance imaging for detection of embolic source after ischemic stroke. J Stroke Cerebrovasc Dis 2012;21:794800.

21. Vemmos K, Ntaios G, Savvari P, et al. Stroke aetiology and predictors of outcome in patients with heart failure and acute stroke: a 10-year follow-up study. Eur J Heart Fail 2012;14:211218.

22. Palumbo V, Baldasseroni S, Nencini P, et al. The coexistence of heart failure predicts short term mortality, but not disability, in patients with acute ischemic stroke treated with thrombolysis: The Florence area Registry. Eur J Intern Med 2012;23:552-557.

23. Byun Jl, Jung KH, Kim YD, et al. Cardiac Function and Outcome in Patients with Cardio-Embolic Stroke. PLOS ONE 2014;9:e95277.

24. Kolominsky-Rabas PL, Weber M, Gefeller O, et al. Epidemiology of ischemic stroke subtypes according to TOAST criteria: incidence, recurrence, and long-term survival in ischemic stroke subtypes: a population-based study. Stroke 2001;32:2735-2740.

25. Král M, Šaňák D, Školoudík D. Cardioembolism is the Most Frequent Etiology of an Acute Ischemic Stroke in Patients Admitted within 12 Hours from Symptom Onset - Results of the HISTORY Study. Čes Slov Neurol Neurochir 2016;79/112:6167.

26. Nucera A, Azarpazhooh MR, Alsubaie R, et al. Time is brain: Balancing risk in the treatment of presumed cardioembolic stroke. J Neurol Sci 2017;382:157-160.

27. Kernan WN, Ovbiagele B, Black HR, et al. Guidelines for the Prevention of Stroke in Patients with Stroke and Transient Ischemic Attack: A Guideline for Healthcare Professionals From the American Heart Association/American Stroke Association. Stroke 2014;45:2160-2236.

28. Arvan S, Boscha K. Prophylactic anticoagulation for left ventricular thrombi after acute myocardial infarction: a prospective randomized trial. Am Heart J 1987;113:688-693.

29. Vaitkus PT, Berlin JA, Schwartz JS, Barnathan ES. Stroke complicating acute myocardial infarction. A meta-analysis of risk modification by anticoagulation and thrombolytic therapy. Arch Intern Med 1992;152:2020-2024.

30. Mooe T, Teien D, Karp K, Eriksson P. Left ventricular thrombosis after anterior myocardial infarction with and without thrombolytic treatment. J Intern Med 1995;237:563569.

31. Hurlen $M$, Abdelnoor $M$, Smith $P$, et al. Warfarin, Aspirin, or Both after Myocardial Infarction. N Engl J Med 2002;347:969974.

32. Tomita H, Hagii J, Metoki N, et al. Severity and Functional Outcome of Patients with Cardioembolic Stroke Occurring during Non-vitamin K Antagonist Oral Anticoagulant Treatment. J Stroke Cerebrovasc Dis 2015;24:1430-1437.

33. Sato A, Nozato T, Hikita $H$, et al. Prognostic value of myocardial contrast delayed enhancement with 64-slice multidetector computed tomography after acute myocardial infarction. J Am Coll Cardiol 2012;59:730-738. 